IJßER

ISSN: 2149-5939

\title{
The effectiveness of problem solving strategy in the solution of geometric optics problems
}

\author{
Süleyman Aydın ${ }^{1} \quad$ Seda Keskin ${ }^{2}$
}

Received Date: 10 / 04 / 2017

Accepted Date: $11 / 07 / 2017$

\begin{abstract}
In this study, a number of problem solving methods and problem solving strategies developed by the researcher in the teaching of "Geometric Optics" unit in the 10th grade physics lesson of secondary school were tried to be proved the effectiveness of the students on their academic achievement and attitudes towards optic unit. A mixed method was used in the study. The research was carried out on three groups formed by 95 tenth grade students studying at Erzincan Milli Egemenlik Anatolian High School during the spring semester of 2015-2016 academic year. For Experiment group 1, many problems were solved by traditional method, for experiment group 2, problem solving strategy and for control group, traditional expression method was used. Before and after Denel procedures, Physique Academic Achievement Test developed by Bülbül (2009) and Optical Attitude Scale developed by Şengören (2006) were applied to all three groups. In the analysis of the obtained data, independent t-test and ANOVA in the SPSS 20 package program were used. According to the results of the research, it is seen that the students in the experimental group 2, who were taught by the problem solving strategy, were statistically more successful than the students in the experimental group 1 who solved a large number of problems and the students in the control group in which they were taught by the traditional expression method.
\end{abstract}

Keywords: Physics Problems, Problem Solving Strategy, Geometric Optics, Academic Success.

\section{Introduction}

Even though students often encounter issues related to science subjects in everyday life, science lessons are a difficult field for students (Ünal \& Ergin, 2006; Özgün-Koca et al., 2006; Çoruhlu et al., 2009; Karamustafaoğlu et al., 2012; Yeşilyurt \& Gül, 2009). Research shows that social factors such as class, school, environment, society, family, race, language and culture; genetics factors such as gender, ability; affective characteristics such as motivation, selfperception, anxiety, attitude; and teacher attitudes, factors such as assessment and learning teaching strategies are factors that affect students' failure (Bulut, 2006). In addition, it is a known fact that students have difficulty in relating science lessons to everyday life and are forced to abstract the concrete concepts.

Physics is one of the areas covered by science. Physics is the task of understanding the universe, learning the causes and consequences of events in the environment, and expressing them in mathematical methods (Aydın, 2007). At the same time physics is one of the disciplines that are difficult to understand because it contains concepts that are difficult to understand and that are not explained visually. In order to overcome this fundamental problem, physics lessons should be made more interesting and understandable (Topuz, Gençer \& Bacanak, 2013; Sarı, 2015; Alptekin et al., 2009). According to Ery1lmaz \& Akdeniz (2013) from Docktor, Strand \& Mestre (2010), the main purpose of the physics course is to understand the basic physics concepts and the second is to develop problem-solving skills. Therefore, it is necessary to use different methods and techniques in order to increase the students' knowledge of physics and to make teaching and

\footnotetext{
${ }^{1}$ Agri Ibrahim Cecen University, Faculty of Education, Agri, Turkey, yupul@hotmail.com

2 sedakeskin 91@hotmail.com
} 
Aydın, S., Keskin, S. (2017). The effectiveness of problem solving strategy in the solution of geometric optics problems. International Journal of Social Sciences and Education Research, 3(5), 1471-1477.

learning more enjoyable (Akçadağ, 2010; Başcı \& Gündoğdu, 2011; Karataş \& Güven, 2003; Çorlu, 2014).

Problem-solving skills need to be taught from childhood and developed during school years. The technique used for problem solving in the form of "given-desired-solution", which is often used in primary school levels, is an important stage in which this evolving infrastructure can be created. The inclusion of problem-solving training in education allows for the development of high-level cognitive skills such as thinking styles (scientific, critical, reflective, creative, analytical, etc.) and problem solving in students. Gaining problem solving skills for students should also be considered as important issues in science and physics teaching (Demir, Maskan et al., 2009; Saracaloğlu, Serin \& Bozkurt, 2001). As the most basic component of science education, physics is the most specific field in which conceptual and operational learning are used together in terms of its subjects. One of the topics that emphasize conceptual and operational knowledge in science education and especially in physics education is the optical conception. Also teaching of the optics is very important because it is the basis for learning some other topics in the physics curriculum program. For this reason, the understanding and solution of geometric optics problems requires the conceptual and operational learning to be carried out together.

The purpose of this study is to compare the academic achievement of the students who solve a large number of problems in the geometric optics unit of the 10th class physics course and the academic achievements of the students who solve the problems using the problem solving strategies in the same subject. At the same time to determine the effect of teaching problem solving strategy on students' attitudes towards optical unit.

\section{Methodology}

Research model: Because of the combined use of quantitative and qualitative data in the study, the research model is a mixed method. Mixed method researches focus on the collection and analysis of both quantitative and qualitative data in a single study (Duban \& Yelken, 2010).

Universe and Sampling: The research was carried out on the $10^{\text {th }}$ grade students studying in an Anatolian high school in Erzincan city in Turkey in the second half of the 2015-2016 academic year. The sample of the study consisted of 95 students in the tenth grade of this high school. 32 students in experiment group 1, 32 students in experiment group 2 and 31 students in control group took part.

Data Collection Tools: In this research, "Physics Academic Achievement Test" developed by Bülbül (2009), "Optical Attitude Scale" developed by Şengören (2006) and face-to-face interview questions developed by the researcher were used as the data collection tolls. The Cronbach alpha reliability coefficient of the PAAT applied to the experiment 1, experiment 2 and control groups as the pre-test by the investigator was calculated as 0,67 and the reliability coefficient of the OAS was 0,60 . Kalayc1 (2005) stated that the scales with $.60 \leq \alpha<.80$ are "highly reliable".

Analysis of Data: In the analysis of quantitative data, independent $t$ - test included in SPSS 20 package program and one - way ANOVA for independent samples were applied and the results were interpreted statistically according to the level of significance $p<.05$. The analysis of qualitative data was analyzed using descriptive analysis technique.

Implementation of the study: In the research 10/A, 10/B and 10/C classes were applied to the Physics Academic Achievement Test developed by Bülbül (2009) as pre-test and post-test. The 
Aydın, S., Keskin, S. (2017). The effectiveness of problem solving strategy in the solution of geometric optics problems. International Journal of Social Sciences and Education Research, 3(5), 1471-1477.

data obtained in the pre-test were subjected to the ANOVA test in the SPSS 20 packet program and because there was no statistically significant difference was between the classes $(p=0,114$, $\mathrm{P}>0,005$ ), the groups were selected as "Experiment group 1", "Experiment group 2" and "Control group" randomly. The study was carried out by the researcher him/herself in the control and experimental groups. In the study groups; reflections in plane mirrors, convex mirrors and concave mirrors, image formation in mirrors, refraction in convex lenses and concave lenses and image formation in lenses in the unit of geometric optics were taught. In experiment group 1, a number of problem solving methods were applied while problem-solving strategy was applied in experiment group 2. In the control group, expression the subjects of geometric optics and problem solutions method were made on the basis of traditional method. The related problem solving strategy consists of 4 stages. These;

1. Analyzing: The phase of the onset of the problem. "Aware of the problem/understanding phase". It is the first step in the conceptual dimension of the problem.

2. Synthesis: The step of combining the information that the knowledge learned to solve the problem. It is the conceptual dimension of the problem and the phase in which the learned knowledge is integrated into the mind.

3. Representation: The stage in which the information to be used for the solution of the problem is transferred on a figure. It is the first step of the operational dimension of the problem.

4. Solution: The data shown on a figure and transferred into the appropriate physical formulas solved and then adapted and interpreted to the physical realities. At this stage, the problem is solved and the result of the solution of the problem is discussed and tested for conformity with the physical reality.

\section{Findings}

In this section, the findings and interpretations of the data collected in the research are presented as a result of statistical analysis.

Table 1. t-test results between pre-test and post-test of control group

\begin{tabular}{|l|c|c|c|c|c|c|}
\hline Tests & $\mathbf{N}$ & $\overline{\boldsymbol{X}}$ & $\mathbf{s s}$ & $\mathbf{t}$ & $\mathbf{p}$ & $\mathbf{F}$ \\
\hline Pre-test & 31 & 4,8387 & 1,18594 & $-4,283$ & 0,000 & 2,090 \\
\cline { 1 - 4 } Post-test & 31 & 6,3871 & 1,62640 & & & \\
\hline
\end{tabular}

$\mathrm{P}<0.05$

Table 1 shows the t-test results between the pre-test and post-test scores of the control group. It is understood from the table that there is a statistically significant difference between PAAT pretest and post-test scores applied to the control group and that this difference is favorable for the post-test $(\mathrm{p}<0,05)$.

Table 2. t-test result between the experiment group 1 pre-test-and post-test

\begin{tabular}{|l|c|c|c|c|c|c|}
\hline Tests & $\mathbf{N}$ & $\overline{\boldsymbol{X}}$ & $\mathbf{s s}$ & $\mathbf{t}$ & $\mathbf{p}$ & $\mathbf{F}$ \\
\hline Pre-test & 32 & 5,5625 & 1,56447 & $-5,849$ & 0,000 &, 972 \\
\cline { 1 - 3 } Post-test & 32 & 8,2813 & 2,11346 & & & \\
\hline
\end{tabular}


Aydın, S., Keskin, S. (2017). The effectiveness of problem solving strategy in the solution of geometric optics problems. International Journal of Social Sciences and Education Research, 3(5), 1471-1477.

Table 2 shows the t-test averages between the pre-test and post-test scores of the control group. The Physics Academic Achievement Test applied to the control group shows a statistically significant difference between the pre- and post-test averages and it is understood from the table that this difference is in favor of the final test $(\mathrm{P}<0.05)$.

Table 3. The average scores of pre-test and post-test of experimental group 1

\begin{tabular}{|l|c|c|c|c|c|c|}
\hline Tests & $\mathbf{N}$ & $\overline{\boldsymbol{X}}$ & $\mathbf{s s}$ & $\mathbf{t}$ & $\mathbf{p}$ & $\mathbf{F}$ \\
\cline { 1 - 5 } Pre-test & 32 & 5,5625 & 1,56447 & $-5,849$ & 0,000 &, 972 \\
\cline { 1 - 4 } Post-test & 32 & 8,2813 & 2,11346 & & & \\
\hline
\end{tabular}

According to Table 3, it is seen that the average score of 32 students in experiment group 1 increased from 5.56 to 8.28 and this difference is statistically significant $(t=-, 849: \mathrm{p}<0.05)$.

Table 4. t-test results of pre-test and post-test of experimental group 2.

\begin{tabular}{|l|c|c|c|c|c|c|}
\hline Tests & $\mathbf{N}$ & $\overline{\boldsymbol{X}}$ & $\mathbf{s s}$ & $\mathbf{t}$ & $\mathbf{p}$ & $\mathbf{F}$ \\
\hline Pre-test & 32 & 8,7813 & 2,35186 & $-6,780$ & 0,000 & 4,915 \\
\cline { 1 - 4 } Post-test & 32 & 13,8125 & 3,47746 & & & \\
\cline { 1 - 4 } & & & & & & \\
\hline
\end{tabular}

Table 4 shows the average scorest test between pre-test and post-test scores of experiment group 2. The relevant table indicates that the final test score average of the experiment group 2 in which the Problem Solving Strategy is applied is higher than the pre-test point average. As can be seen from the table, it is understood that the results of the independent $\mathrm{t}$-test between the success pre-test and post-test of the experimental group 2, in which the problem solving strategy is applied, is statistically significant $(\mathrm{P}<0.05)$.

Table 5. t-test average scores of post-tests between the experiment group 1 and experiment group 2.

\begin{tabular}{|l|c|c|c|c|c|c|}
\hline Groups & $\mathbf{N}$ & $\overline{\boldsymbol{X}}$ & $\mathbf{s s}$ & $\mathbf{t}$ & $\mathbf{p}$ & $\mathbf{F}$ \\
\hline Experiment 1 & 32 & 8,2813 & 2,11346 & $-7,689$ & 0,000 & 7,509 \\
\cline { 1 - 4 } Experiment 2 & 32 & 13,8125 & 3,47746 & & & \\
\hline
\end{tabular}

In Table 5, it is seen that the success level of the experiment group 2 in which the problem solving strategy is applied is higher than the success level of experiment group 1 which solves many problems with the conventional method.

Table 6. t-test scores of post-tests between the groups experiment 1 and control.

\begin{tabular}{|l|c|c|c|c|c|c|}
\hline Groups & $\mathbf{N}$ & $\overline{\boldsymbol{X}}$ & $\mathbf{s s}$ & $\mathbf{t}$ & $\mathbf{p}$ & $\mathbf{F}$ \\
\hline Experiment 1 & 32 & 8,2813 & 2,11346 & 3,978 &, 000 & 1,036 \\
\cline { 1 - 4 } Control & 31 & 6,3871 & 1,62640 & & & \\
\hline
\end{tabular}


Aydın, S., Keskin, S. (2017). The effectiveness of problem solving strategy in the solution of geometric optics problems. International Journal of Social Sciences and Education Research, 3(5), 1471-1477.

It is understood from Table 6 that the independent $t$ test results of the posttests are statistically significant between the experiment group 1 in which many problems are solved and control group in which the traditional lecture method is applied. In other words, it can be said that experiment group 1 , which has many problems solved, is more successful than the control group.

Table 7. Average scores of t- test between control and the experimental group 2.

\begin{tabular}{|l|c|c|c|c|c|c|}
\hline Groups & $\mathbf{N}$ & $\overline{\boldsymbol{X}}$ & $\mathbf{s s}$ & $\mathbf{t}$ & $\mathbf{p}$ & $\mathbf{F}$ \\
\cline { 1 - 4 } Control & 31 & 6,3871 & 1,62640 & \multirow{2}{*}{$-10,798$} & \multirow{2}{*}{0,000} & \multirow{2}{*}{13,644} \\
\cline { 1 - 5 } Experiment 2 & 32 & 13,8125 & 3,47746 & & & \\
\hline
\end{tabular}

Table 7 shows that the average of post-test of the control group is lower than the post-test average of the experiment group 2. According to these results, the success level of the experiment group 2 in which the problem solving strategy is applied is higher than the success level of the control group in which the traditional method is used ( $p>, 005)$.

\section{Result and discussions}

It was determined that there was a statistically significant difference between PAAT average scores of pre-test and post-test of control and experimental groups. In Table 3, when the pre-test and post-test average scores of the students in experiment group 1, in which a large number of problem solving methods were used, were taken from PAAT, the post test scores averages are higher than the pre-test averages As seen in Table 2 likewise, in the achievement test, post-test average score of control group was higher than the pre-test average score (Bayrak, 2008). When the students' averages scores of pre-test and post-test were examined in the experiment group 2 where the problem solving strategy was applied, it was seen that the post-test averages were higher than the pre-test averages (see, Table 4) (Kıray, 2003).

The average score of PAAT final test score of experiment group 1 was 8.28 while the average score of PAAT post test score of experiment group 2 was found to be 13.81. According to these results, from the average points of post-tests, it was seen that there was a significant difference between the experiment group 1 and the experiment group 2 in favor of experiment group 2 . This implies that the teaching method supported by the problem solving strategy is more effective than the conventional problem solving method. Byun \& Lee (2014) solved an average of 2200 sciencerelated problems in their work and investigated the academic achievement of students in solving these problems. As a result of their study, they stated that although the students solved a large number of problems, there was no statistically significant relation between the academic achievements at the end of the applied physics competition. When the PAAT scores of experiment group 1 and the control group were examined (Table 5), it was seen that there was a significant difference in favor of experiment group 1. It was seen that from the results of PAAT there was a meaningful difference in favor of experiment group 2 when the PAAT applied to the students of the control group where the traditional method was applied and the experiment group 2 where the problem-solving strategy was applied (Table 6). Similarly, Doğruluk (2010) concluded that the problem-solving method enhances the academic achievement of students and that the learning influences the academic success in a positive way, resulting in parallel to the results of this study. It was stated that the problem solving strategies applied in the studies were more effective than 
Aydın, S., Keskin, S. (2017). The effectiveness of problem solving strategy in the solution of geometric optics problems. International Journal of Social Sciences and Education Research, 3(5), 1471-1477.

the traditional methods (Kıray, 2003; Oğuz, 2002; Yazgan, 2007; Yazgan \& Bintaş, 2005; Galili \& Hazan, 2000; Hubber, 2005; Buty \& Mortimer, 2008).

Problem solving using problem solving strategy, was found to increase students' academic achievement towards optical unit. It is thought that physics teachers should use this strategy or develop different strategies to increase the students' academic achievement.

\section{References}

Akçadağ, T. (2010). Öğretmenlerin İlköğretim Programındaki Yöntem Teknik Ölçme ve Değerlendirme Konularına İlişkin Eğitim İhtiyaçları. Ahmet Yesevi Üniversitesi Bilig Dergisi, 53, 29-50.

Alptekin, S., Demirbaş, M. \& Arıkan, N. (2009). 9. Sınıf Öğrencilerinin Fizik Dersine İlişkin Görüşlerinin İncelenmesi. Bilim Kurulu/Advisor Board, $1,1$.

Aydın, S. (2007). Geometrik Optik Konusundaki Kavram Yanılgılarının Kavramsal Değişim Metinleri ile Giderilmesi. Yayınlanmamış Doktora Tezi. Fen Bilimleri Enstitüsü, Erzurum.

Başc1, Z. \& Gündoğdu, K. (2011). Öğretmen Adaylarının Drama Dersine İlişkin Tutumları ve Görüşleri: Atatürk Üniversitesi Örneği. Ilkogretim Online, 10(2).

Bayrak, N. (2008). Yapılandırmacı Öğrenme Yaklaşımının Beş Aşamalı Modeline Uygun Olarak Geliştirilen Ders Yazılımı ve Çalışma Yapraklarının Öğrencilerin Başarısına, Öğrenilen Bilgilerin Kalıcılıgına ve Öğrencilerin Fen Bilgisi Dersine Yönelik Tutumlarina Etkisinin İncelenmesi. Yayınlanmamış Yüksek Lisans Tezi, Atatürk Üniversitesi, 136 s., Erzurum.10(2).

Bülbül, O. (2009). Fizik Dersi Optik Ünitesinin Bilgisayar Destekli Öğretiminde Kullanılan Animasyonların ve Simülasyonların Akademik Başarıya ve Akılda Kalıcılığa Etkisinin İncelenmesi. Yayınlanmamış Yüksek Lisans Tezi, Çukurova Üniversitesi, Sosyal Bilimler Enstitüsü, Adana.

Bulut, S. (2006). İlköğretim II. Kademe Öğrencilerinin Matematik Dersinde Kullandıkları Öğrenme Stratejileri ve Başarı Güdüleri.

Buty, C. \& Mortimer E.F. (2008). Dialogic/Authoritative Discourse and Modelling in a High School Teaching Sequence on Optics, International Journal of Science Education, 30(12), 1635-1660.

Byun, T. \& Lee, G. (2014). Why Students Still Can't Solve Physics Problems After Solving Over 2000 Problems. American Journal of Physics, 82(9), 906-913.

Çorlu, M. S. (2014). Call for Manuscripts on STEM Education. Turkish Journal of Education, 3(1).

Çoruhlu, T. Ş., Nas, S. E. \& Çepni, S. (2009). Fen ve Teknoloji Öğretmenlerinin Alternatif ÖlçmeDeğerlendirme Tekniklerini Kullanmada Karşılaştıkları Problemler: Trabzon Örneği.

Demir, C., Maskan, A. K., Çevik, Ş. \& Baran, M. (2009). Ortaöğretim 9. Sınıf Fizik Ders Kitabının Ders Kitabı Değerlendirme Ölçütlerine Göre İncelenmesi. Dicle University Journal Of Ziya Gokalp Education Faculty, 13.

Doğruluk, M. (2010). Sekizinci Sınıf Fen ve Teknoloji Dersi “Kuvvet ve Hareket” Ünitesinin Öğretiminde Problem Çözme Yönteminin Öğrenci Başarısına Etkisi. Yayınlanmamış Yüksek lisans tezi, Celal Bayar Üniversitesi. Fen bilimleri Enstitüsü, Manisa.

Duban, N. \& Yelken, T. Y. (2010). Öğretmen Adaylarının Yansıtıcı Düşünme Eğilimleri ve Yansitıcı Öğretmen Özellikleriyle İlgili Görüşleri. Çukurova Üniversitesi Sosyal Bilimler Enstitüsü Dergisi, 19(2).

Eryılmaz, S. \& Akdeniz, A. R. (2013). 10. Sinıfta Yer Alan "Kuvvet ve Hareket" Ünitesiyle İlgili Problemleri Çözerken Öğretmenlerin Sergiledikleri Adımlar. Hacettepe Üniversitesi Eğitim Fakültesi Dergisi, 28(28-3).

Galili, I. \& Hazan, A. (2000). Learners' Knowledge in Optics: İnterpretation, Structure and Analysis, Journal of Research in Science Teaching, 22 (1), 57-88. 
Aydın, S., Keskin, S. (2017). The effectiveness of problem solving strategy in the solution of geometric optics problems. International Journal of Social Sciences and Education Research, 3(5), 1471-1477.

Hubber, P. (2005). Explorations Of Year 10 Students' Conceptual Change During İnstruction, Asia-Pacific Forum On Science Learning And Teaching, 6(1),1-27.

Kalaycı, Ş. (2005). SPSS Uygulamalı Çok Değişkenli İstatistik Teknikler, Asil Yayın Dağıtım, Ankara.

Karamustafaoğlu, O. \& Sontay, G. (2012). Bir Timss Sınavının Ardından: Tımms (2011)'e Katılan Öğrenci ve Uygulayıcı Öğretmenlerin Görüşleri. "X. Ulusal Fen Bilimleri ve Matematik Eğitimi Kongresi” (X. UFBMEK), 27-30 Haziran 2012, Niğde.

Karataş, İ. \& Güven, B. (2003). Problem çözme davranışlarının değerlendirilmesinde kullanılan yöntemler: Klinik mülakatın potansiyeli. Illköğretim Online, 2(2), 2-9.

Kıray, S.A. (2003). İlköğretim 7. Sınıflarda Fen Bilgisi Dersinde Uygulanan Problem Çözme Stratejisinin Ögrencilerin Kavramları Anlama ve Problem Çözme Performansları Üzerine Etkisi, Yayınlanmamış Yüksek Lisans Tezi, Selçuk Üniversitesi Fen Bilimleri Enstitüsü, Konya.

Oğuz, M. (2002). İlköğretim Fen Bilgisi Dersinde Yaratıcı Problem Çözme Yönteminin Başarıya ve Tutuma Etkisi, Yayınlanmamış Yüksek Lisans Tezi, Hacettepe Üniversitesi, Ankara.

Özgün-Koca, S. A. \& Şen, A. I. (2006). Orta Ögretim Öğrencilerinin Matematik ve Fen Derslerine Yönelik Olumsuz Tutumlarinin Nedenleri. Eurasian Journal of Educational Research (EJER), (23).

Saracaloğlu, A. S., Serin, O.\& Bozkurt, N. (2001). Dokuz Eylül Üniversitesi Eğitim Bilimleri Enstitüsü Öğrencilerinin Problem Çözme Becerileri Ile Başarıları Arasındaki Ilişki.

Sarı, M. (2015). Teknik Bilimler Meslek Yüksek Okulu Öğrencilerinin Fizik Dersine İlişkin Düşünceleri ve Fizik Dersinden Başarısızlıklarını Olumsuz Etkileyen Faktörlerin Öğrenci Görüşlerine Göre Değerlendirilmesi.

Şengören, S. (2006). Optik Dersi Iş̧ıta Girişim ve Kırınım Konularının Etkinlik Temelli Öğretimi: İşbirlikli Öğrenme Yönteminin Etkilerinin Araştırılması, Yayınlanmamış Doktara Tezi, Dokuz Eylül Üniversitesi Eğitim Bilimleri Enstitüsü Ortaöğretim Fen Ve Matematik Alanlar Eğitimi, İzmir.

Topuz, F. G., Gençer, S., Bacanak, A.\& Karamustafaoğlu, O. (2013). Bağlam Temelli Yaklaşım Hakkında Fen ve Teknoloji Öğretmenlerinin Görüşleri Ve Uygulayabilme Düzeyleri. Amasya Üniversitesi Eğitim Fakültesi Dergisi, 2(1), 240-261.

Ünal, G. \& Ergin, Ö. (2006). Buluş Yoluyla Fen Öğretiminin Öğrencilerin Akademik Başarılarına, Öğrenme Yaklaşımlarına ve Tutumlarına Etkisi. Türk Fen Eğitimi Dergisi, 3(1), 36-52.

Yazgan, Y. \&Bintaş, J. (2005). İlköğretim Dördüncü ve Beşinci Sınıf Öğrencilerinin Problem Çözme Stratejilerini Kullanabilme Düzeyleri: Bir Öğretim Deneyi. Hacettepe Üniversitesi Eğitim Fakültesi Dergisi, 28(28).

Yazgan, Y. (2007). Dördüncü ve Beşinci Sınıf Öğrencilerinin Rutin Olmayan Problem Çözme Stratejileriyle İlgili Gözlemler. İlköğretim Online, 6(2).

Yeşilyurt, S. \& Gül, Ş. (2009). Biyoloji Tutum Ölçeği. Erzincan Eğitim Fakültesi Dergisi, 11(2), 239-258. 